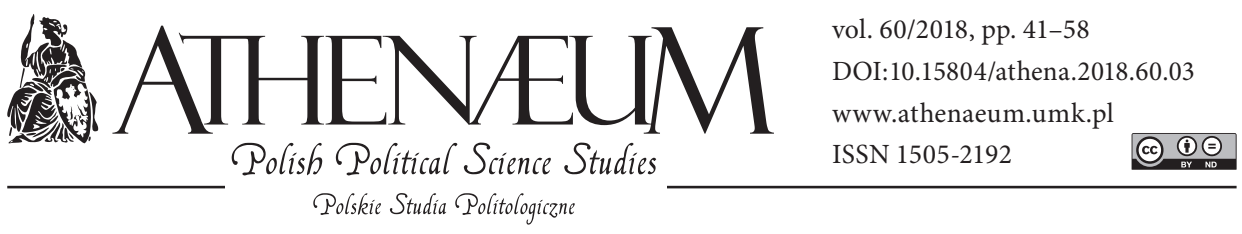

\title{
THE SONGUN DOCTRINE AS THE MOST IMPORTANT FACTOR OF INTERNAL AND INTERNATIONAL POLICY OF NORTH KOREA
}

\author{
DOKTRYNA SONGUN JAKO NAJWAŻNIEJSZY CZYNNIK \\ POLITYKI WEWNĘTRZNEJ I MIĘDZYNARODOWEJ \\ KOREI PÓŁNOCNEJ
}

Andrzej Purat*(i), Paweł Bielicki ** (1)

\begin{abstract}
The subject of our interest is to present the significance of the Songun doctrine (Military First) in the North Korea's internal and international politics. At the beginning, we intend to trace the concept of the Juche ideology and its essential implications for the role of the army in a country ruled by the Kim dynasty since the end of World War II. In the remainder of this study, we would like to characterize the theoretical and explanatory aspects of the Songun doctrine, focusing in particular on reviewing of its principles in terms of politics, economy, culture and propaganda aspects. In the context of the current situation in the Democratic People's Republic of Korea, an important role is played by the Byungjin doctrine, initiated by the country's leader Kim Jong-un and mentioned in our article, which in the future can contribute to the beginning of reforms in Korea's economy. In summary, we presented forecasts for
\end{abstract}

Przedmiotem naszego zainteresowania jest przedstawienie znaczenia doktryny Songun (armia pierwsza) w polityce wewnętrznej i międzynarodowej Korei Północnej. Na wstępie zamierzamy prześledzić pojęcie ideologii dżucze i jej zasadniczych implikacji dla roli wojska w kraju rządzonym przez dynastię Kimów od zakończenia II wojny światowej. W dalszej części niniejszej analizy chcielibyśmy scharakteryzować aspekty teoretyczno-eksplanacyjne doktryny Songun, zwracając szczególną uwagę na rozpatrywanie jej zasad w wymiarze politycznym, ekonomicznym, kulturalnym oraz propagandowym. Ogromnie istotnym problemem poruszonym $\mathrm{w}$ naszym artykule, obecnym w kontekście sytuacji w Koreańskiej Republice Ludowo-Demokratycznej, jest także zainicjowana przez przywódcę kraju Kim Dzong Una doktryna Byungjin, mogąca w przyszłości przyczynić się

* Kazimierz Wielki University in Bydgoszcz, Faculty of Humanities.

** Kazimierz Wielki University in Bydgoszcz, Faculty of Humanities. 
the future and our attempt to answer the question whether in the current international situation the Songun doctrine will be implemented in its present form.

Keywords: doctrine, ideology, Juche, Songun, Byungjin, DPRK, USA, Kim Il-sung, Kim Jong-il, Kim Jong-un do zapoczątkowania reform gospodarki kraju. W podsumowaniu przedstawiliśmy prognozy na przyszłość i podjęliśmy się próby odpowiedzi na pytanie, czy w dobie współczesnej sytuacji międzynarodowej doktryna Songun będzie realizowana w dotychczasowej formie.

Słowa kluczowe: doktryna, ideologia, dżucze, Songun, Byungjin, KRLD, USA, Kim Ir Sen, Kim Dzong Il, Kim Dzong Un

\section{INTRODUCTION}

The most recent events in North Korea and threats to use force against Kim Jongun's regime by the new President of the United States, Donald Trump, encourage us to study the meaning of the Songun doctrine in both internal and foreign policy of North Korea. This country, which has been in international isolation for decades and suffered economic crisis, wants to develop its nuclear program at any cost, which will assure regime survival. However, not only construction and development of nuclear weapons by DPRK communists is an important factor to maintain dictatorship of the Workers' Party of Korea. Despite the attempts to limit the influence of the army by the current state leader, Kim Jong-un, this instrument of power continues to play a significant role in shaping the political system, which the young dictator cannot ignore. The army as the main beneficiary of the existing policy of militarization of the country and supremacy in the field of influencing the society constitutes - next to the party - the most important part of the internal and external policy of the DPRK. Therefore, we are interested in the description of the Songun doctrine, which has been in force to this day with some modifications implemented by the current satrap, an ideology that in some way develops the most important assumptions of the policy conducted by the Workers' Party of Korea abroad, as well as in military, family and cultural aspects. In addition, we intend to answer the question if the Byungjin concept promoted by Kim Jong-un focused on strengthening of nuclear potential of the country with simultaneous implementation of economic reforms has an opportunity to succeed in the coming years. In the beginning, however, we need to explore the genesis of the Songun doctrine, which derives from the Juche concept. 


\section{JUCHE IDEOLOGY AND ITS CONSEQUENCES}

North Korea, which had been in the Soviet zone of influence since 1945, had referred to strong military traditions since the beginning of its existence. Kim Il-sung, appointed personally by Joseph Stalin as the state leader, born on April 15,1912 , was presented by propaganda as guerilla leader of military groups fighting against the Japanese invader. Supposedly he was appointed general at the age of 14. What's interesting, when he arrived to Korea, Kim had problems with speaking his native language due to long absence in the country resulting from his life in exile in the Soviet Union (Szyc, 2012). The Soviet propagandists accurately noticed that Asian societies are intrinsically accustomed to the tradition of obedience to authority in accordance with the concepts of Confucianism. They also believed that references to military symbols will contribute to the increasing support to the leader and Kim's cult of personality. However, in the case of North Korea, during the initial years of Kim Il-sung's rule the assumptions mentioned above were not implemented in any way. Until Stalin's death in March 1953 and the "Secret Speech" delivered by Nikita Khrushchev at the 20 $0^{\text {th }}$ Congress of the Communist Party of the Soviet Union, Kim Il-sung was quite compliant with the USSR. This compliance was visible in particular in the context of the documents, from which we can deduce that the Korean asked the dictator for permission to a military campaign in South Korea in 1950 (Pichoja, 2011, p. 45; cf. March 05, 1949. Meeting Between Stalin and Kim Il Sung; May, 1950. Record of a Conversation of Cde. Stalin with Kim Il Sung and Pak Heon-Yeong). After a final armistice agreement was reached in Panmunjom on July 27, 1953, Kim, who was disappointed with insufficient economic support coming from Soviet and Chinese communist regimes, started to look for the third option, which was neutrality between both powers and decoupling North Korea from any outside influences. It was achieved thanks to the Juche ideology, announced officially by the Korean leader in December 1955. In the military aspect, the Juche idea was implemented starting from 1964, when it was announced that "the Juche idea promotes the military-first policy, which allows to defend the achievements of revolution against U.S. imperialist aggression". Its content was expanded three years later, concurrent with formulation of the ten principles for the establishment of a monolithic ideological system. In practice, it meant orders directed to party officials. They include - "The entire society has to function according to the ideology of the Great Leader Kim Il-Sung. The society has to adhere strictly to the principle of unconditional obedience to the Great 
Leader. The authority of Kim Il-Sung is absolute. Disobeying the Great Leader is not allowed under any circumstances. Kim Il Sung's orders have to be accepted unconditionally. The party constitutes unity, centering on Kim Il-Sung. One has to learn everything from the Great Leader. One shall be grateful for political life given by Kim Il-Sung and trust him completely. The entire nation has to have a strong discipline and be obedient to the Great Leader Kim Il-Sung. Revolution initiated by the Leader has to be continued in the future" (Dziak, 2004, p. 58; cf. Gryniewicz, 2010).

The Juche philosophy was reviewed in four categories. According to Alicja Bartuś (2014), it should be divided into self-reliance in ideology, politics, economy and national defense. The first one specified autonomy in creating a brand new culture and ideology that differed from the ones in the past, based on praising the state leaders and attacking the alleged enemies of "Korean people", mainly the USA and South Korea. In addition, it anticipated breaking with tradition and history from before the communist period, referring to outside ideologies of the reigning dynasty. The second concept was self-reliance in politics. It assumed independent international policy aimed at striving to maintain sovereignty and independence at any price by isolation of the country from any outside influences. The idea mentioned above was accompanied by self-reliance in economy, which consisted in complete autarky and reluctance to any form of external dependence of the country with increased economic "efficiency" of an average Korean. The last concept was self-reliance in defense of the country, based on establishing of its own army by North Korea, militarization of people in their fight against "American and South Korean imperialists", maintaining complete autonomy and independence in the national defense process (Bartuś, 2014, pp. 50-51). Prof. Waldemar Dziak, an expert in North Korea, emphasizes that the main purpose of the Juche propaganda during the times of Kim Il-sung was promotion of the model of "Kim Il-sung's man". Such person, according to the author, was subordinate only to the "Great Leader". The main goal was to create a man completely obedient to authority, blindly relying on its activities. It was facilitated by education of people from a young age, making sure that they serve Kim Il-sung with great conviction as a natural impulse rather than under compulsion. There was a theory about "an immortal social-political life" of an individual, which in combination with the leader as the Devine Being is eternal and everlasting (Dziak, 2003, p. 210). It means that it is an "honor" to every Korean to praise the Great Leader as a perfect man, deprived of any flaws and shaped by the army. No major tangible benefits should be earned for work. 
The perfection of Kim Il-sung or his son will never be achieved by a common resident of North Korea.

Another opinion on the Juche ideology, with which we should agree, is presented by B.R. Myers (2011). According to him, this idea was developed in order to depict Kim Il-sung as a great thinker, ardent nationalist, supported by humanist principles and concern for autonomy and independence (Myers, 2011, p. 40). The opinion of this author is not baseless, since Kim, being aware of the new "trends" in the Kremlin after the death of the head of the Soviet State, was looking for an original path to build social support. It was explained in, among others, his speech from December 28, 1955, entitled "On Eliminating Dogmatism and Formalism and Establishing Juche in Ideological Work". The commander clearly stated in it that one cannot copy all Soviet methods of rule, saying that: "there should be no set rule that we must follow the Soviet pattern. Some advocate the Soviet rule and others the Chinese, but is it not high time to work out our own?" (Dziak, 2000, p. 217). He cleverly utilized all nationalistic and chauvinistic trends that were present at that time in the North Korean nation, deepened by injustices suffered during occupation of the country and Japanese cruelty of the past war and in the first half of the $20^{\text {th }}$ century. Therefore, counting on increasing support among his people, Kim Il-sung, concentrating military around himself as a driving force of nationalism, was striving to strengthen the sense of hostility among the Koreans to all other nations that protest against violation of basic human rights by the regime. This trend had been promoted for many decades, leading to the development of foundations for a separate military doctrine in the 1990s.

\section{THEORETICAL-EXPLANATORY ASPECTS OF THE SONGUN DOCTRINE}

Defining the Songun doctrine, the North Korean authorities supported the idea of prioritizing the Army in social and political activities of the DPRK. The origins of the Songun doctrine date back to the period between the late $1980^{\text {s }}$ and the early 1990s, concurrent with the weakening power of Kim Il-sung and the rising power of his son Kim Jong-il, who was appointed by his father as his successor at the congress of the Workers' Party of Korea in 1980. Facing new challenges in terms of politics and economy, problems and the ultimate demise of the USSR, economic reforms in China and establishing by both powers diplomatic relation 
with the eternal enemy of Pyongyang - South Korea - Kim Jong-il started to strengthen his power and deepen isolation of his country in the international arena. It was facilitated by, among others, the Rangoon bombing conducted earlier at his order in October 1983 and detonation of a bomb onboard a South Korean airplane in November 1987, just before the Olympic Games in Seoul, which killed 115 people. Based on collected materials and reports of some highranking North Korean officials who defected to the Wests in the 1990s, it will be justified to put forward a thesis that Kim Jong-il's policy was not approved by his father. The old dictator, which had for decades been one of the most farsighted politicians of Asia, in the end of his rule realized that it would be necessary to conduct economic reforms maintaining North Korea's totalitarian regime. Playing a game of cat and mouse with the West in the case of nuclear potential, Kim Il-sung prepared the foundation for certain, then undefined, changes. Such suggestion is put forward by Prof. Dziak (2004) in Poland's only biography of Kim Jong-il, and Nicolas Levi, an expert in North Korea's elites, quoted by Konrad Klonowski (Dziak, 2004, pp. 47-48; cf. N. Levi, 2013). Grażyna Strnad, a respected researcher on the Korean Peninsula (2014), writes that the North Korea's leader, despite his critical attitude to Chinese economic reforms, facing economic problems and the cooling of relations between the new President of Russia Boris Yeltsin and North Korea, was willing to perform an unspecified modification of the system in the country and foreign policy of the DPRK, turning once again for assistance to China, which can be confirmed by the visit of Kim Il-sung to China in October 1991 and signing of an agreement on reconciliation, nonaggression and exchanges and cooperation between North and South Korea (Strnad, 2014, pp. 278-279). The economic condition of the DPRK after 1991 is accurately described by journalist Barbara Demick confirming that "Without cheap fuel oil and raw material, it couldn't keep the factories running, which meant it had nothing to export. With no exports, there was no hard currency, and without hard currency, fuel imports fell even further and the electricity stopped. The coal mines couldn't operate without electricity, and the shortage of coal worsened the electricity shortage. The electricity shortage further lowered agricultural output" (Fischer, 2015, p. 205). The deteriorating economy was accompanied by an increase in Kim Jong-il's personal control over the army; in 1992, he was appointed Supreme Commander of the Korean People's Army, continuing a purge of military officials that he deemed disloyal. After the death of Kim Il-sung, which circumstances remain unclear, on July 8, 1994, just before the meeting between the dictator and the President of South Korea, Kim Jong-il 
had certain problems with strengthening his power, which was confirmed by naming his deceased father "Eternal President".

In the process of gaining full power, the dictator's son relied primarily on military. That is why, starting from the mid-1990s, the Songun ideology has been present in the public space of the DPRK. The word "Songun" means righteousness, honesty, truth or glory, but both the DPRK and the West adopted its different meaning. It assumes constant, systematic strengthening of the army, which is prioritized in allocation of resources from the state budget. In accordance with the mentioned idea, the leader has to establish an army, which can defend the country in every situation, regardless of internal and external conditions. The state that follows the Songun ideas is reluctant to any external influences, the Army is needed only during the war, but it should play the crucial role in all fields of life. Realizing the necessity of strengthening the support of the army for his activities, on January 1, 1995, the new leader of the country sent a letter to soldiers. We read in it: "The essence of the Songun policy is to defend security of the country and the revolutionary gains by strengthening the People's Army as an invincible revolutionary armed forces and build up the driving force of the revolution and conduct all activities for socialist construction in a revolutionary militant manner with the People's Army as a core and a main agent integrating North Korean society" (cf. Songun Chongch'i [Army First]). In 2003, indicating the genesis of the doctrine, he said that the main reason of its development were political system changes in East-Central Europe, saying that "Our party started pursuing Songun politics based on the scientific analysis of the international circumstances of our revolution [...]. Entering the 1990s, socialism collapsed in the former Soviet Union and the Eastern European countries, giving rise to a great change in the world political structure and balance of forces. [...] The reactionary imperialist forces spearheaded their attack towards our Republic, which is advancing constantly under the banner of independence, the banner of socialism" (Dziak, 2013, pp. 227-228). We also need to focus our attention on the time of the formal recognition of Songun as the official doctrine of the country. The beginning of the millennium in North Korea marked the consequences of the famine from the 1990s. In order to maintain power, Kim Jong-il was sort of forced to sign a treaty with military officials who demonstrated their will to play a stronger role in shaping the political system of the country. It was clearly suggested that it serves to "ensure continuity of the rule of the late Kim Il-sung" (Byung-ro, 2004, p. 101). In addition, the warming of relations between the two Koreas was reaching an end, initiated in the end of the past decade by the 
"Sunshine Policy" of Kim Dae Jung, the President of South Korea, which resulted in the Inter-Korean summit in Pyongyang with Kim Jong-il and talks between the dictator and Madeleine Albright, the U.S. Secretary of State under the Administration of President Bill Clinton. The change in American administration in January 2001 and the transfer of power to George Bush, a Republican, changed Washington's rhetoric on the DPRK, which inevitably led to deterioration of mutual relations and depicting the United States of America in North Korean propaganda as the main enemy of the state and warmonger. The situation was made even worse when Bush named the DPRK as one of countries of the socalled "Axis of Evil", along with Iraq and Iran, financing international terrorism and breaking all human rights. It is no coincidence that in the beginning of the new millennium, North Korea increased its spending on the army, which led to strengthening of the Songun idea in the society by military mobilization motivated by defense against foreign intervention. Therefore it can be reasonably assumed that the Songun ideology has both internal and external grounds.

\section{SONGUN PRINCIPLES IN NORTH KOREAN POLITICAL SYSTEM}

In terms of interpretation of the Songun idea, one shall look at its principles. They are fundamental for understanding the situation in the DPRK. The Songun dogmas, presented by one of the most important North Korean theoreticians, Prof. K.P. Chon, serve as manifestations of the army's influence on social life. The military must live and die with Soryong to the end. This implies that every soldier's commitment and devotion to the leader is absolute and unconditional, and the military will achieve its assigned goals at all costs, with no regard for victims. For a soldier, the most important goal is defense of the nation, rather than material issues. Individual activity of man is meaningless. What matters most is a collective work for the greater good. Discipline that plays the most important role in the North Korean Army is the core of all actions, and the remaining members of the society have to be absolutely loyal to one another, if it does not violate the interest of the nation, primarily the Workers' Party of Korea (Park, 2007).

Further strengthening of the role of Songun was sort of sealed by adoption of a new constitution of the country in 2009. The term communism was deleted in articles 29 and 40. Military issues were enumerated in articles 100 to 105. Based on them, it is entirely clear the Chairman of the National Defense Commission 
is the Great Leader of the DPRK (note that the Commission was dissolved in 2016), and his term is the same as the management staff, and he is the Supreme Commander of the whole armed forces of the DPRK and commands and directs all the armed forces of the State. The most precise, however, is article 103, according to which the Chairman of the Commission has duties and authority to direct the overall affairs of the State, to personally guide the work of the Commission, to appoint or remove key cadres in the field of national defense, to ratify or rescind major treaties concluded with other countries, to exercise the right of granting special pardon, and to proclaim a state of emergency, a state of war and mobilization order within the country. He also issues orders and is accountable to the Supreme People's Assembly (Petrov, 2009).

In the economic aspect, the Songun doctrine makes the defense industry the core of the economic structure, followed by light industry and agriculture, which are considered coequally secondary. Due to this reason, the primacy of the army over economy makes that the economic situation of North Korea continues to be in dire straits. It is rightly emphasized that the military industry is the only one that brings in certain revenues. In accordance with the official data, military expenses of the DPRK generate 25\% of GDP, and unofficially as much as $50 \%$ (Dąbrowski, 2017). These days, the army has 20,000 artillery pieces, 1,000 short- and medium-range missiles, 70 submarines, more than $400 \mathrm{patrol} / \mathrm{missile}$ boats and 563 combat aircraft, with more than 1.2 million armed men. However, according to former American Army Intelligence Officer Michael Pregent, North Korea's military is armed with obsolete conventional weapons, but it can threaten and destroy a significant part of Seoul in South Korea (Wallace, 2017).

The situation is similar in education. In the DPRK, military education starts from a young age, focused on popularization of the cult of army as an invincible power, resisting Western countries, in particular the United States of America and South Korea. Focus is placed on the central role of the military in the "patriotic" education of the nation, highlighting the necessity of defense against American imperialism. 14-year-old children get military training, regardless of gender. They learn how to use weapons and precise shooting, firing to, among others, targets fashioned after American soldiers. The most meaningful motivation is the one that regards learning of foreign languages by Korean children. Indicating the necessity of learning the language of the enemy - English and Japanese - North Korean children learn military vocabulary, in accordance with Kim Il-sung's "recommendation", that says that young people do not have to speak these 
languages, but understand the basic military terms such as "arms down", "hands up", "surrender" (cf. Learning or Drill?).

In the family aspect, they present and require a military and traditional family model, based on the dominating role of the husband and a significant number of children. Woman in North Korea is not empowered and is frequently submissive to her man. Despite the officially atheist propaganda of the DPRK, we rarely see cohabitating couples. Families whose parents or children are on active duty receive from the state a larger food ration and additional perquisites. When children are in military training areas, the government sends special helpers to their families in order to assist them in household chores (Park, 2007).

A special role in the Songun doctrine is played by culture and propaganda. It is the key for the authorities in Pyongyang to have control over society. Referring to military traditions by ruling officials constitutes an important component of the forced integration between society and the army, as well as a reliable way for mobilization in terms of ideology. The most frequently presented arts refer to the military topics of defense of Korea against the USA and South Korea. A special role in this matter is played by choirs promoted by North Korean television. They are expected to shape the "revolutionary awareness" of a DPRK citizen. In addition, Western cultural influences, perceived as "decadent", are sharply criticized in North Korean culture. Black and white propaganda used by the authorities is seen in particular in many propaganda films, glorifying North Korean armed forces, in particular their size and alleged level of technological advancement (Park, 2007).

However, the essence of the Songun doctrine is reflected primarily in the foreign policy of North Korea. Propaganda, from the beginning of this state, emphasizes that the military force of the DPRK and other "progressive" countries will make possible removing of Americans from Asia and "peaceful" unification of the Korean Peninsula. In communist media, politicians and military in Seoul are perceived as American puppets, financed by the military factors of Washington. Therefore, according to North Korean political and military factors, South Korea should not be treated as a serious partner in international relations of Asia. In the opinion of the propagandists of Pyongyang, defeating of "imperialists" will be possible after unification of the opponents of American policy and a joint attack on South Korea, obviously when the USA and South Korea strike first. The North, involved in aggressive foreign policy, based on strong army, tries to state that it strives to stabilize situation on the Korean Peninsula (Park, 2007). We have to notice that in the second decade of this century, we can notice 
some trends in activities of the leader of the Korean state, which are aimed at changing the status quo in terms of the primacy of the military zone and the role of representatives of military administration in almost all fields of political and social-economic life.

\section{KIM JONG-UN'S POLICY AND ATTEMPTS TO LIMIT ROLE OF MILITARY APPARATS IN THE POLICY OF NORTH KOREA}

After the death of Kim Jong-il of a heart attack on December 17, 2011, his son Kim Jong-un, born in 1983 or 1984 (the exact date unknown), was appointed as his successor. International community and the Koreans themselves have been convinced that the young leader, educated in Switzerland, would become a hope for political and economic changes. However, due to the specificity of the North Korean rule system, it has been known from the beginning that such changes would not happen in the near future. Having the support of the military, Kim Jong-un had skillfully carried out his goals to maintain his power, showing towards his opponents brutality, not seen in the party management of the country since his father's removal of competitors to Kim Il-sung's legacy. The youngest of Kims, aware of the restrained support from his immediate family, started purges from first removal from the party and later the killing of Jang Song Thaek, his uncle and husband of the sister of the late dictator. Most likely, this execution was the revenge for lack of support to the candidacy of Kim Jong-un as successor of his father from the sister of the late dictator, Jang's wife, in 2008. Regardless of the actual reasons of his political fall and death, his removal started purging within military elites, reluctant to the rules of the present leader of the state. Kim Jong-un, getting rid of influential generals, was guided by two goals. Firstly, he wanted to strengthen his political power and control over the army. Secondly, it seems justified a statement that in this way he worked on development of his position in the management that would allow him to carry out economic reforms without asking for opinions from chief officials. It is no secret that the success of reforms could depend on reduction on spending on the army. In the meantime, Kim Jong-un did not officially abandon the Songun doctrine until 2013. During his first public speech at the event celebrating the centennial of the birth of Kim Il-sung, the new leader of the DPRK confirmed further strengthening of the North Korean Army, stating that expansion of the army is the "first, second and third" task of the state. According to him, North Korea 
established a strong army, ready to offense and defense (Bartuś, 2014, p. 53). In April 2013, he said that "Songun was the General's [Kim Jong-Il] revolutionary idea, his practice in the revolution, his political ideal and his political mode..." In terms of strengthening of the Korean People's Army as the most important instrument in the Songun policy, he described it as "the buttress, the main force of our revolution" and "[Kim Jong-Il] achieved the historic victory in the grim anti-imperialist, anti-US showdown in defense of the country's security and socialism" by strengthening of the army (Songun Chongch'i [Army First]). The strong emphasis on the army seen in the speech was another attempt to convince the military that the current political direction, based on the power of the army, would be continued. We need to mention a special time for delivering his first speech. The first months of 2013 marked escalation of tensions on the Korean Peninsula, caused by American - South Korean military exercises alongside the North Korean border. It seems justified that Kim Jong-un, strengthening his power at that time, did not want to antagonize the army and formally guaranteed continuation of the Songun line. There was the risk that the situation may get out of hand, but it was clear that the Korean leader, considering a significant advantage of the American nuclear potential, would not risk a war. Pyongyang's provocations have been used to strengthen the control of the current head of state over the army, just like the frequent visits of the leader to the military units stationed alongside the border (Malm, 2014). Educated in Europe, the dictator is well aware of the fact that quality of life in the West and other countries is so much higher than in his homeland. The North Korean authorities also realize that reforms are necessary. The first serious idea of the young Kim in this matter is development of a doctrine, which is described below.

\section{THE BYUNGIIN IDEOLOGY AND ITS POSSIBLE IMPLICATIONS FOR THE POLITICAL SITUATION IN NORTH KOREA}

Considering the statements on strengthening the leading role of the army in the DPRK, it would be justified to claim that Kim Jong-un does not think about any fundamental economic reforms, striving to continue the rule of his father. In reality, formulation of the Byungjin idea constitutes a certain modification of theories that have been present in North Korean propaganda. The discussed concept literally means economic development in relation to the possessed nuclear potential. The beginning of the Byungjin doctrine is referred to Kim 
Jong-un's New Year's Speech of January 1, 2014. In it, he formulated five crucial assumptions for development of the country. Firstly, a strong emphasis on an external nuclear threat and the development of Korean own nuclear capabilities. Secondly, continuing praise of scientists in the defense industries of the DPRK, developing military hardware that is "light, unmanned, intelligent and of high precision", i.e., drones. Thirdly, a continued emphasis on "ambitious" construction, including entertainment facilities, residential buildings and economic projects that benefits Pyongyang the most, but is also having no negative impact on the countryside. Fourthly, it will be justified to focus on power generation to help modernize the national economy. And finally, fifthly, focus less on ideology and more on actual policies, which reflects Kim Jong-un's personal views (Frank, 2014).

It seems that Kim Jong-un realizes that in times of the changing international situation, the Songun ideology starts to be dysfunctional. For this purpose, the leader looks for an original concept, which according to his belief, would be able to save the regime. It is supported by the information on establishing the Space Agency of North Korea and new missile tests in 2017, condemned every time by the international community. In addition, it is worth mentioning that the $4^{\text {th }}$ session of the Supreme People's Assembly disbanded the National Defense Commission, replaced with the State Affairs Commission, which in addition to Kim Jong-un as its chairman includes all important officials of the North Korean Party serving as deputy chairmen, both military officials and heads of economic departments (Pietrewicz, 2016). The makeup of the commission confirms that Kim Jong-un added representatives of both law enforcement and economic agencies. It allows to assume that in the coming years, military will play a less important role than so far, but it will remain one of the most significant players in the North Korean policy.

The pretext to broader considerations on the Byungin doctrine was the 2016 Congress of the Workers' Party of Korea. In became a kind of coronation of Kim Jong-un as leader of the country. It also served as an opportunity to highlight the meaning of the new doctrine. During the sessions, emphasis was placed on an increase of nuclear weapons stockpiles in terms of quality and quantity, at the same time stressing that the DPRK does not want to use nuclear weapons and strives to assure peace on the Korean Peninsula through direct talks with Seoul and Washington on normalization of relations, to ease tension and reduce armed forces stationing on the demarcation line between North and South Korea. A statement of the Congress, published by the KCNA agency, specifies 
that a potential attack from South Korea will be crushed by the army from North Korea, and the nuclear program of the country will be maintained as long as "the imperialists present a nuclear threat", and nuclear development of the country is necessary due to the "hostility of the United States of America" (Martin, 2016). According to Prof. Dziak (2016), the official Songun doctrine is still maintained, but in practice the party increases its role, since Kim Jong-un does not want to be dependent on the army. According to an analyst, the military consists of ideological "fossils", afraid of changes and loss of influences and positions. "And if not the army, then what's left is the party. The Congress will pick a new political bureau, new central committee and will appoint Kim Jong-un as its chairman. It will strengthen the position of Kim and the party, increasing the control over the army. That's why the first congress of the party in 36 years is needed" (cf. Parfieniuk, 2015). On the other hand, American publicists J. Person and A. Isozaki claim that development of the Byungin ideology proves the unwillingness of the DPRK to abandon its nuclear program and intention to continue its policy as a deterrent. What is interesting, they criticize the US policy against Pyongyang. According to their opinion, American political elites misinterpreted the DPRK management as irrational, unpredictable and aggressive people. These stereotypes make impossible more sober analyses of the actual situation in the DPRK and true motivation of the country leadership. At the same time, the authors indicate that the Korean top officials drew the conclusion from past experiences of other totalitarian regimes and developed an answer to new challenges, in case of which the Byungjin ideology is one of the initial signs (Person \& Isozaki, 2017).

International reactions to the Byungjin doctrine were very laconic and restrained. Park Geun-hye, former President of South Korea who was impeached, described it as a "far-fetched assertion" that was unrealistic. Another researcher from the Korean Institute for National Unification in Seoul, Kim Gap-Sik, stated that this program is unrealistic because it pursued "nuclear first, economy second". There was also an opinion expressed by Chung Chang-Hyon, Director of the Institute of Korean Modern History, who indicated that "there was no change from the previous position of Pyongyang" (Suh, 2016, pp. 4-5). The Byungjin analysis also mentioned that Kim Jong-un in the rudiments of the doctrine refers to Kim Il-sung and the time of economic growth of the country in 1953-1961. Afraid of U.S. intentions to overthrow his government, it is possible that he realized that he should prevent a similar scenario in Pyongyang. Therefore, on the one hand, in addition to continuation of terror, they should implement economic reforms (Cathcart, Winstanley-Chesters, \& Green, 2017, 
p. 13). It seems fair to state that one of the first signs of implementation of the new doctrine took place in early 2015, when North Korea began reaching out diplomatically to Russia, Southeast Asia and Africa, lessening its dependence on China. These efforts have had little success, and North Korea remains unable to significantly expand ties with foreign partners (cf. Military and Security Developments Involving the Democratic People's Republic of Korea, p. 3). B. Seliger says that the Byungjin doctrine confirms that North Korea's strategy of bullying was unsuccessful, since warning foreign diplomats of a coming war while at the same time wooing foreign tourists and investors does not work. The author also states that the simultaneous development of nuclear potential and economy of the country cannot be reconciled with long-term development goals. On the other hand, there is some economic logic in Kim's policy - scaling down of the army accompanied by its modernization and increased spending on consumption. The author concludes that with time the DPRK authorities should focus on one direction of development. First of all, they have to make the country credible in the eyes of Western businessmen and significantly increase North Korea's trade with the rest of the world, particularly the part that remains neutral to the parties to the dispute on the Korean Peninsula. According to the author, tests of nuclear weapons and missile launches will not help, since they increase threat perception in other countries, not only in South Korea (Seliger, 2014, p. 26). We can agree with the analysts, since in many countries the problem of development of the Korean army is completely misunderstood. Sparse information from the DPRK, received mainly from defectors and anonymous diplomats, draw a picture of this country isolated from the rest of the world and identify it as a threat for the entire world. Therefore, there is no doubt that in long term, the DPRK would have to choose if it wants to follow the path of Chinese reforms and pragmatism in economic and military affairs, or it will continue on its current course, which vision is presented by the Songun doctrine.

\section{CONCLUSION}

Considering the above - is there a future for the Songun doctrine? In our opinion, the DPRK will be involved in the process of gradual departure from the "military first" policy and strengthening of consumption factors, maintaining its tough stance. We cannot expect any significant changes in short term, but preliminary reforms can start right now. 
The article was motivated by the current events faced by North Korea. Slowly, it seems clear that the time of taking full power by Kim Jong-un seems to be close and we can count on the possibility of gradual implementation of certain promising economic ideas. We can notice that the dictator, aware of a low standard of living in North Korea, realizes that another delaying of reforms can lead to his fall. It cannot be excluded that once again the expected changes will be torpedoed by Kim's inner circle, including his family, army and the theoretical advisors from the Organization and Guidance Department, having the vast majority of responsibilities in the scope of internal and external policy of the country. The North Korean ruling elite sense that success of economic reforms can lead to the loss of its influence. Due to the traditions of inborn obedience and the use of ruthless political terror, we should not expect an outbreak of organized social protests. The society will not risk a highly probable defeat. In North Korea, like in no other country in the world, there is no open or hidden opposition to the authorities, and isolation from the world makes it impossible for any social self-organization to exist. Therefore, a slow departure from the Songun doctrine will not change political situation in the country, but depending on receiving permission from Kim Jong-un and his associates, it can contribute to improvement of economic condition of the society and gradual decoupling from China. Departure from North Korea's dependence on the Central State means return to the times of Kim Il-sung, who had for years skillfully balanced the Soviet Union and China against each other, trying to stay neutral between the two powers. Referring to the cult of the state founder and only modifying Kim Jong-il's assumptions can improve the international situation of the country and thus its economy, but only in an ineffective, short-term perspective. Will they succeed in these new undertakings? We have to wait for an answer to this question a little bit longer.

\section{REFERENCES:}

Bartuś, A. (2014). Korea Północna - państwo totalitarne zagrażające bezpieczeństwu globalnemu. Zarys problemu. Chorzowskie Studia Polityczne, 7, 47-70.

Byung-ro, K. (2004). Sytuacja praw człowieka w Korei Północnej. In: A. Rzepliński, \& J. Hosaniak (eds.), Korea Pótnocna za zasłona (pp. 99-113). Warszawa: Helsińska Fundacja Praw Człowieka.

Cathcart, A., Winstanley-Chesters, R., \& Green C. (2017). Introduction. In: A. Cathcart, R. Winstanley-Chesters, \& C. Green (eds.), Change and Continuity in North Korean Politics (p. 13), Routhledge: Taylor and Francis Group. 
Dąbrowski M., (2017). Asymetryczna odpowiedź i zastraszanie. Militarne filary reżimu Korei Północnej (opinia). Defence 24. Retrieved from: http://www.defence24. pl/588596,asymetryczna-odpowiedz-i-zastraszanie-militarne-filary-rezimu-koreipolnocnej-opinia.

Dziak, W. (2000). Kim Ir Sen. Dzieło i polityczne wizje. Warszawa: Wydawnictwo TRIO, Instytut Studiów Politycznych Polskiej Akademii Nauk.

Dziak, W. (2003). Korea. Pokój czy wojna? Warszawa: Świat Książki.

Dziak, W. (2004). Kim Jong-il. Warszawa: Wydawnictwo TRIO, Instytut Studiów Politycznych Polskiej Akademii Nauk.

Dziak, W. (2013). Kim Dzong Un. Kronika życia i walki. Warszawa: Instytut Studiów Politycznych Polskiej Akademii Nauk.

Fischer, P. (2015). Kim Dzong Il - Thriller i sensacja. Katowice: Sonia Draga.

Frank, R. (2014). A Guide to Kim Jong-un's 2014 New Year's Speech. Retrieved from: http://www.38north.org/2014/01/rfrank010214/.

Gryniewicz, M. (2010). Rozwój ideologii w Korei Północnej - od juche (dżcze) do songun - czesść 1. Retrieved from: http://pukhan.pl/2010/04/rozwoj-ideologii-wkorei-polnocnej-od-juchedzucze-do-Songun-czesc-1/.

Idea Juche [On the Juche Idea]. Retrieved from: http://krld.pl/krld/juche.

Levi, N. (2013). Śmierć Kim Ir Sena (druga część). Retrieved from: http://pukhan. $\mathrm{pl} / 2013 / 07 /$ smierc-kim-ir-sena-druga-czesc/.

March 05, 1949. Meeting Between Stalin and Kim Il-sung. Retrieved from: http://digitalarchive.wilsoncenter.org/document/112127.

Martin, S. (2016). N. Korea Party Congress Pushes Nuclear Weapons Expansion. Retrieved from: https://www.dailymaverick.co.za/article/2016-05-09-n.-koreaparty-congress-pushes-nuclear-weapons-expansion\#.WPAog2ekLIU.

May, 1950. Record of a Conversation of Cde. Stalin with Kim Il-sung and Pak Heon-Yeong. Retrieved from: http://digitalarchive.wilsoncenter.org/document/114905.

Military and Security Developments Involving the Democratic People's Republic of Korea: Report to Congress. Retrieved from: https://www.defense.gov/Portals/1/Documents/ pubs/Military_and_Security_Developments_Involving_the_Democratic_Peoples_Republic_of_Korea_2015.PDF.

Myers, B.R. (2011). Najczystsza rasa. Propaganda Korei Północnej. Warszawa: PWN.

Parfieniuk, A. (2015). Pierwszy kongres partii w Korei Północnej od 36 lat. Kim Dzong Un odejdzie od polityki ojca? Retrieved from: https://wiadomosci.wp.pl/ pierwszy-kongres-partii-w-korei-polnocnej-od-36-lat-kim-dzong-un-odejdzieod-polityki-ojca-6027729352569985a.

Park, H.S. (2007). Military-First Politics (Songun): Understanding Kim Jong-il's North Korea. Academic Paper Series, 2(7), 1-8. Retrieved from: http://keia.org/sites/ default/files/publications/hanpark.pdf.

Pichoja, R. (2011). Historia władzy w Związku Radzieckim 1945-1991. Warszawa: PWN. Person, J., \& Isozaki, A. (2017). Want to Be a Successful Dictator? Copy North Korea. Retrieved from: http://nationalinterest.org/feature/want-be-successful-dictatorcopy-north-korea-19726? page=3-. 
Pietrewicz, O. (2016). Komisja według Kim Dzong Una. Żegnaj songun, witaj byungjin! Retrieved from: http://www.polska-azja.pl/o-pietrewicz-komisja-wedlug-kimdzong-una-zegnaj-Songun-witaj-byungjin/.

Seliger, B. (2014). From Watchful Peace to Lasting Security. The Security Times, 26.

Songun Chongch'i [Army First]. Retrieved from: https://www.globalsecurity.org/military/world/dprk/songun-chongchi.htm.

Strnad, G. (2014). Korea. Polityka Południa wobec Północy w latach 1948-2008. Zmiana i kontynuacja. Wydawnictwo Instytutu Zachodniego.

Suh, J.J. (2016). Half Full or Half Empty? North Korea after the $7^{\text {th }}$ Party Congress. The Asia-Pacific Journal- Japan Focus, 14(9), 1-9.

Szyc, S. (2012). Fałszywa legenda Kim Ir Sena. Retrieved from: http://historia.org. $\mathrm{pl} / 2012 / 12 / 18 /$ falszywa-legenda-kim-ir-sena/.

Wallace, C. (2017). North Korea's Army: 1.2M Men, Obsolete Equipment and Nukes. Retrieved from: http://www.foxnews.com/world/2017/04/28/north-koreas-army1-2m-men-obsolete-equipment-and-nukes.html.

Woody, C. (2017). China Appears to Be Making a Key Concession on North Korea. Retrieved from: http://www.businessinsider.com/china-north-korea-coal-imports2017-4?IR=T. 